International Journal of Current Advanced Research

ISSN: O: 2319-6475, ISSN: P: 2319 - 6505, Impact Factor: SJIF: 5.995

Available Online at www.journalijcar.org

Volume 6; Issue 4; April 2017; Page No. 3144-3146

DOI: http://dx.doi.org/10.24327/ijcar.2017.3146.0205

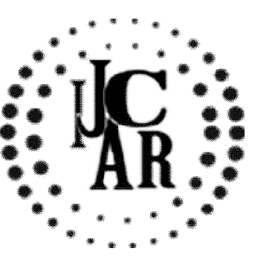

Research Article

\title{
AWARENESS ON COMPLICATIONS OF DIABETES MELLITUS AMONG DIABETIC PATIENTS IN CHENNAI
}

\section{Gokul.G}

Saveetha Dental College Chennai-077

\section{A R R T I C L L E I N F O}

\section{Article History:}

Received $10^{\text {th }}$ January, 2017

Received in revised form $19^{\text {th }}$ February, 2017

Accepted $16^{\text {th }}$ March, 2017

Published online $28^{\text {th }}$ April, 2017

\section{Key words:}

Diabetes mellitus,

awareness, complications

\begin{abstract}
A B S T R A C T
Aim: To find the awareness levels on complications of diabetes mellitus among diabetic patients in Chennai.

Objective: The patients are asked questions on their knowledge of complications of diabetes such as heart diseases, diabetic foot, kidney and neural problems, etc.

Background: Diabetes mellitus is a disease rampant in today's society due to the extravagant lifestyles and food habits followed by masses. It affects many people and is hereditary, but many people do not take any action against it due to lack of awareness on its effects and complications. This leads to heavy complications and health effects and may even lead to disability, high discomfort and sometimes death.

Result: From the data obtained, the awareness on diabetic complicationsi was found to be well (Mean $\%=64.25)$ and very low number of patients (Mean $\%=35.37)$ were found to be unaware of them. Awareness on poor wound healing $(90 \%)$, diabetic foot $(82 \%)$, hypertension (74\%) and eye problems (73\%) were higher than the others.
\end{abstract}

Copyright $(\mathbf{C} 2017$ Gokul.G. This is an open access article distributed under the Creative Commons Attribution License, which permits unrestricted use, distribution, and reproduction in any medium, provided the original work is properly cited.

\section{INTRODUCTION}

Diabetes mellitus (DM), commonly referred to as diabetes, is a group of metabolic diseases which leads to high blood sugar levels over an extended period of time [1] and has emerged as one of the most challenging public health problems in the current century has over 366 million people worldwide suffering from DM and this figure is likely to double by 2030 [2,3 ]. The load of DM is felt in low and middle-income countries, and these nations account for about $80 \%$ of all cases of diabetes [4] When the diabetic patients do not properly keep it in control, it may lead to lifelong complications, which quite commonly lead to increased morbidity and mortality [5][6].

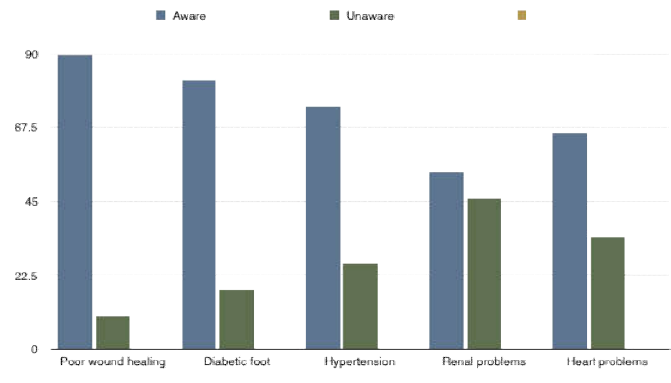

Fig 1 Diabetic complications.

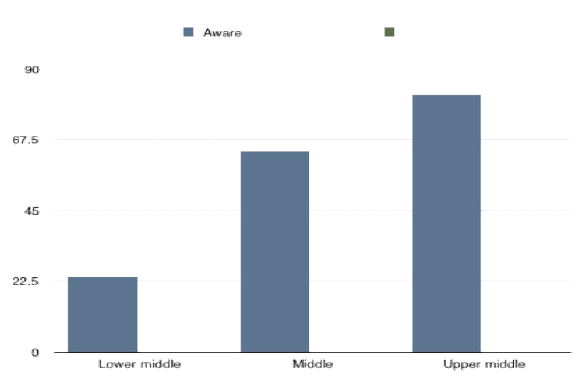

Fig 2 Socioeconomic status
For instance, poorly controlled diabetes, can cause damage to eyes (blindness), kidneys (renal failure), and nerves (leading to impotency and foot disorders/possibly amputation) as well as higher risk of heart disease, stroke, and poor blood supply to the limbs.Most of these complications areirreversible and expensive to manage as they generally need management in specialized centers or rehabs with sophisticated infrastructure and equipment, competant staff and potent medications.[7] A person diagnosed with diabetes tend to have an increased risk of stroke and heart diseases compared to the normal population and increased incidence of retinopathy, peripheral nerve damage and renal problems[8].

\section{*Corresponding author: Gokul.G}

Saveetha Dental College Chennai-077
Other studies have shown that increasing patient knowledge regarding diabetes mellitus and its complications have significant benefits with respect to patient compliance 
acquiescence to treatment and help in decreasing the complications associated with it.[9]Few researchs have been done into the knowledge and management including health education of the disease [10-14]

\section{MATERIALS AND METHODS}

A set of questions based on diabetic complications were given to diabetic patients (both type 1 and type 2) and then the data was analysed and graphs were produced.The questionnaire was given to 100 patients from Saveetha Dental College. methodology for estimating global and national prevalence of diabetes in adults. Diabetes Res Clin Pract.

3. Shaw JE, Sicree RA, Zimmet PZ. Global estimates of the prevalence of diabetes for 2010 and 2030. Diabetes Res Clin Pract. 2010

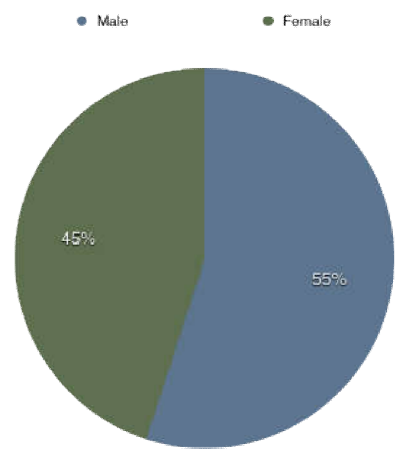

Fig 4 Sex

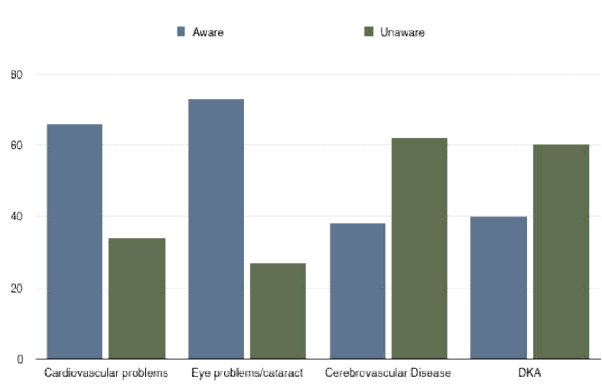

Fig 5 Diabetic complications-2.

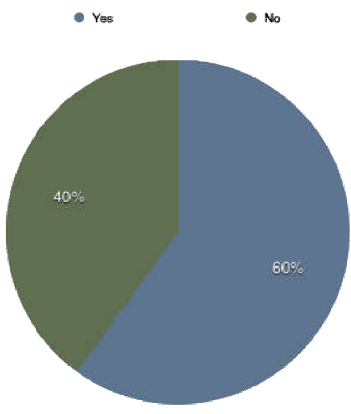

Fig 6 Awareness on hyperglycemia

Table 1 Diabetic complications awareness

\begin{tabular}{|c|c|c|c|c|c|c|c|c|c|}
\hline & $\begin{array}{l}\text { Poor wound } \\
\text { healing }\end{array}$ & Dabotic foot & Hypertension & Aenal problems & $\begin{array}{l}\text { Cardiovascular } \\
\text { problems }\end{array}$ & $\begin{array}{l}\text { Eye problems/ } \\
\text { cataract }\end{array}$ & & $\begin{array}{l}\text { Cerebrovascular } \\
\text { Disease }\end{array}$ & DKA \\
\hline Aware & g & & 82 & 74 & 54 & 66 & 73 & 38 & 40 \\
\hline Unaware & 1 & & 18 & 26 & 46 & 34 & 27 & 62 & 60 \\
\hline
\end{tabular}

\section{DISCUSSION}

From the data obtained,the awareness on diabetic complications was found to be well(Mean $\%=64.25)$ and very low number of patients (Mean $\%=35.37$ ) were found to be unaware of them.Awareness on poor wound healing $(90 \%)$, diabetic foot $(82 \%)$, hypertension $(74 \%)$ and eye problems (73\%) were higher than the others.

The awareness on diabetic complications are found to known by most of the diabetic patients and known less by patients in the lower middle class and lesser regular visits to doctors were found in the samecategory and higher incomefamilies and the presence of a family history of diabetes were found to be positively associated with more knowledge and is consistent with the current study. [15] It is widely known that excessive sugar intake is a risk factor for incident diabetes mellitus [16], the present study indicates almost $46 \%$ are aware about intake of sugar. Individuals with a positive family history of a disease may develop a personal sense of vulnerability which, in turn, may increase their awareness, which was revealed in the present study [17] Dyslipidemia is a common feature of DM and needs to be treated because of the potential complications especially artherosclerosis.[18] Therefore, more awareness on the seriousness of diabetes must be made and its complications should be made sound.

\section{References}

1. About diabetes". World Health Organization. Archived from the original on 31 March 2014

2. GuariguataL, Whiting D, Weil C, Unwin N. The international diabetes federation diabetes atlas
4. Ping Zhang XZ, Brown J, Vistisen D, Richard Sicree JS, Nichols G. Global healthcare expenditure on diabetes for 2010 and 2030. Diabetes Res Clin Pract. 2010; 13:293-301. doi: 10.1016/j.diabres. 2010.01.026

5. Hall V, Thomsen R, Henriksen O, Lohse N. Diabetes in Sub Saharan Africa 1999-2011: Epidemiology and public health implications. a systematic review. BMC Public Health. 2011

6. Alberti KG, Zimmet PZ. Definition, diagnosis and classification of diabetes mellitus and its complications. Part 1: diagnosis and classification of diabetes mellitus. Provisional report of a WHO consultation. Diabet Med. 1998

7. Alla MAaS. Diabetes in Sub-Saharan Africa: Kenya, Mali, Mozambique, Nigeria, South Africa and Zambia. Int J Diabetes Dev Ctries. 2008

8. Control CfD, Prevention, Control CfD, Prevention National diabetes fact sheet: national estimates and general information on diabetes and prediabetes in the United States, 2011. Atlanta: US Department of Health and Human Services, Centers for Disease Control and Prevention; 2011

9. Murugesan N, Snehalatha C, Shobhana R, Roglic G, Ramachandran A. Awareness about diabetes and its complications in the general and diabetic population in a city in southern India. Diabetes Res Clin Pract. 2007

10. Kengne AP, Amoah AG, Mbanya J-C. Cardiovascular complications of diabetes mellitus in sub-Saharan Africa. Circulation. 2005 
11. Boulton AJ, Kirsner RS, Vileikyte L. Neuropathic diabetic foot ulcers. $N$ Engl J Med. 2004

12. Hall V, Thomsen RW, Henriksen O, Lohse N. Diabetes in Sub Saharan Africa 1999-2011: epidemiology and public health implications. A systematic review. $B M C$ Public Health. 2011

13. Desalu O, Salawu F, Jimoh A, Adekoya A, Busari O, Olokoba A. Diabetic foot care: self reported knowledge and practice among patients attending three tertiary hospital in Nigeria. Ghana Med J. 2011

14. Aikins A-G. Healer shopping in Africa: new evidence from rural-urban qualitative study of Ghanaian diabetes experiences. BMJ. 2005
15. Al Shafaee WMA, Al-Shukaili S, Rizvi SGA, et al. Knowledge and perceptions of diabetes in a semiurban Omani population. BMC Public Health 2008; 8: 249-256.

16. 22. Johnson RJ, Segal MS, Sautin Y, Nakagawa T, Feig DI, Kang DH, Gersch MS, Benner S, SánchezLozada LG: Potential role of sugar (fructose) in the epidemic of hypertension, obesity and the metabolic syndrome, diabetes, kidney disease, and cardiovascular disease. Am J Clin Nutr. 2007

17. Walter FM, Emery J, Braithwaite D, Marteau TM: Lay understanding of familial risk of common chronic diseases: a systematic review and synthesis of qualitative research. Ann Fam Med. 2004

18. Gheena, S., T. Chandrasekhar, and Pratibha Ramani. "Salivary characteristics of diabetic children." Brazilian Journal of Oral Sciences 10.2 (2011): 93-97.

\section{How to cite this article:}

Gokul.G (2017) ' Awareness On Complications Of Diabetes Mellitus Among Diabetic Patients In Chennai', International Journal of Current Advanced Research, 06(04), pp. 3144-3146.

DOI: http://dx.doi.org/10.24327/ijcar.2017.3146.0205 